\title{
ANALISIS KONFLIK ATAU SENGKETA HAK KEPEMILIKAN TANAH ADAT BETANG SANGKUWU DI DESA TUMBANG MARAK, KECAMATAN KATINGAN TENGAH, KABUPATEN KATINGAN, KALIMANTAN TENGAH
}

\author{
Dedy Ilham Perdana* dan Yuliana** \\ * Dosen Jurusan Sosiologi FISIP Universitas Palangkaraya \\ ** Mahasiswa Jurusan Sosiologi FISIP Universitas Palangkaraya
}

\begin{abstract}
The conflict on the customary land of Betang Sangkuwu in Tubang Marak village occured because of the struggle for the ownership of customary land of Betang Sangkuwu located in the middle of the palm oil processing plantation company, namely PT Karya Dewi Putera (PT KDP). The fight for customary land ownership of Betang Sangkuwu occurred between the indigenous people of Tubang Marak village and the comers settling in this village, called penampil.

This study uses a phenomenological study with a qualitative approach, which examines the phenomenon to be developed. The source of data in this reseach came from primary data, which were collected through direct and in-dept interviews between the researcher and informants (the subject), observations, recordings and field notes. Data analysis techniques used are data reduction, analysis of data, and the conclusion and verification.

The results showed that in the process of customary land disputes in Betang Sangkuwu of Tumbang Marak village there were actors who played roles (roles of authority). The conflict occured because of the root triggered by economic values, social values (social rent/social previlages), and rent ricardian (sacred cultural values).

The conflict was in the form of latent conflict, namely slandering, suspicion, and threatened each other, as well as manifest conflict in the form of blaming each other. Efforts have been made, namely the mediation and hinting (a customary fine) in Dyak customary. The fight for customary land ownership rights of Betang Sangkuwu in Tumbang Marak village has not been completed. The penampil community together with KCW personnels would raise the issue to the positive law. Yet,since the indigenous people of Tumbang Marak village were willing to accept the results of the mediation, the relationship between parties involved the conflict in Tumbang Marak village was getting better.
\end{abstract}

Keywords : Land Dispute, Indigenous Lands, Mediation and Hinting 


\section{PENDAHULUAN}

Sengketa adalah perbedaan nilai, kepentingan, pendapat, dan atau persepsi antara orang per orang atau badan hukum (privat atau publik) mengenai status penguasaan dan atau status kepemilikan dan atau status penggunaan atau pemanfaatan atas bidang tanah tertentu oleh pihak tertentu atau status keputusan tata usaha negara menyangkut penguasaan, pemilikan, dan penggunaan atau pemanfaatan atas bidang tanah tertentu. Sengketa dapat terjadi antar individu, antar individu dengan kelompok, dan antar kelompok dengan kelompok $^{1}$.

Secara sederhana konflik adalah pertentangan yang ditandai oleh pergerakan dari beberapa pihak sehingga terjadi persinggungan. Konflik bisa muncul pada skala yang berbeda seperti konflik antar orang per orang (interpersonal conflict), konflik antar kelompok (intergroup conflict), konflik antar kelompok dengan negara (vertical conflict), konflik antar negara (interstate (conflict) $)^{2}$.

Sengketa yang terjadi di wilayah Desa Tumbang Marak, Kecamatan

\footnotetext{
${ }^{1}$ Limbong, Bernhard. 2012. Konflik pertanahan. Margaretha Pustaka. Jakarta. Hlm. 48.

${ }^{2}$ Susan Novri. 2010. Pengantar Sosiologi Konflik dan isu-isu Kontemporer. Kencana: Jakarta.
}

Katingan Tengah, Kabupaten Katingan merupakan sengketa tanah adat Betang Sangkuwu. Tanah Betang Sangkuwu berupa kaleka, yaitu tempat pemukiman leluhur masyarakat adat yang sudah menjadi hutan dan dianggap keramat serta diakui sebagai tanah adat yang bersifat komunal $^{3}$. Tanah adat Betang Sangkuwu berada di dekat Sungai Sangkuwu. Luas tanah adat yang diakui oleh pihak perusahaan dan masyarakat Desa Tumbang Marak melalui "Berita Acara Kesepakatan Pembuatan Batas Tanah Adat" yaitu $\pm 25 \mathrm{Ha}$ (dua puluh lima hektar) bertepatan masuk dalam wilayah perusahaan perkebunan pengolahan kelapa sawit PT. Karya Dewi Putera (PT. KDP), Blok L.34, M.33, \& M.34 ${ }^{4}$. PT. Karya Dewi Putera berdiri di wilayah Desa Tumbang Marak pada sekitar tahun 2003, dan mulai beroperasi pada sekitar tahun 2005 .

Sengketa tanah adat Betang Sangkuwu mulai terjadi pada tahun 2005, namun sengketa mulai muncul pada tahun 2013, dan di tahun 2014 sengketa terangkat. Sengketa bermula

\footnotetext{
3 Peraturan Gubernur Kalimantanm Tengah nomor 13 tahun 2009 Tentang Tanah Adat Dan Hak-Hak Di Atas Tanah Di Provinsi Kalimantan Tengah.Usop, Sidik R. Kebijakan Pemerintah Provinsi Kalimantan Tengah Terhadap Masyarakat Adat. 16/12/2014

4 Berdasarkan Berita Acara Kesepakatan Pembuatan Batas Tanah Adat tgl 14 Maret 2005 \& 27 Maret 2005 di Tumbang Marak
} 
dari pengklaiman kepemilikan tanah adat Betang Sangkuwu oleh masyarakat pendatang atau penampil yang menetap di Desa Tumbang Marak, bahwa tanah adat Betang Sangkuwu milik nenek moyang mereka yaitu Temanggung Doho. Pengklaiman diikuti dengan tuntutan yang diajukan oleh pihak kelompok penampil kepada pihak perusahaan PT. Karya Dewi Putera (PT KDP) berupa tuntutan agar Betang Sangkuwu dijadikan situs budaya atas nama nenek moyang mereka yaitu Temanggung Doho, dan meminta pihak perusahaan untuk membayar denda sebesar Rp 32 Miliyar karena telah terpakai tanah adat Betang Sangkuwu oleh pihak perusahaan.

Pengklaiman kepemilikan tanah adat tersebut tidak dapat diterima oleh masyarakat asli Desa Tumbang Marak, sebab berdasarkan versi cerita mereka, tanah adat Betang Sangkuwu merupakan tanah milik nenek moyang masyarakat asli Desa Tumbang Marak yaitu Oko Apang Beren, sehingga masyarakat asli Desa Tumbang Marak pun melakukan tuntutan kepada pihak perusahaan agar tanah adat Betang Sangkuwu dijadikan situs budaya milik masyarakat Desa Tumbang Marak.
Sengketa perebutan hak kepemilikan tanah adat Betang Sangkuwu yang melibatkan dua kelompok masyarakat tersebut menyebabkan konflik antar keduanya, sehingga hubungan kedua pihak yang berkonflik sempat memanas. Namun saat ini, hubungan kedua pihak berkonflik telah meredam. Meskipun sengketa kepemilikan hak belum selesai, kedua pihak yang terlibat konflik telah menempuh upaya penyelesaian secara mediasi dan hinting pali (mediasi secara adat Dayak).

\section{METODE PENELITIAN}

Menurut Bogdan dan Taylor (2002), pendekatan kualitatif adalah melihat dan mendeskripsikan fenomena sosial yang ada di tengah-tengah masyarakat dan melihat kegiatan yang dilakukan masyarakat, merupakan prosedur penelitian yang menghasilkan data deskriptif berupa kata-kata tertulis maupun lisan dari orang-orang dan perilaku yang diamati.

Metode penelitian kualitatif adalah metode penelitian yang berlandaskan pada filsafat postpositivisme, digunakan untuk meneliti pada kondisi obyek alamiah, (sebagai lawannya adalah eksperimen) dimana 
peneliti adalah sebagai instrumen kunci, teknik pengumpulan data secara triangulasi (gabungan), analisis data bersifat induktif/kualitatif, dan hasil penelitian kualitatif lebih menekankan makna daripada generalisasi ${ }^{5}$.

Dalam penelitian ini, peneliti menggunakan pendekatan penelitian kualitatif fenomenologis karena pada hakikatnya penelitian kualitatif menggunakan pendekatan secara fenomenologis. Artinya, peneliti berangkat ke lapangan dengan mengamati fenomena yang terjadi dilapangan secara alamiah ${ }^{6}$.

Ditinjau dari hakekat pengalaman manusia dipahami bahwa setiap orang akan melihat realita yang berbeda pada situasi yang berbeda dan waktu yang berbeda. Jarak, waktu, hubungan manusia, tempat tinggal akan mempengaruhi setiap pengalaman manusia. Metode fenomenologis ini menekankan kepada bagaimana seseorang memaknai pengalamannya ${ }^{7}$.

\footnotetext{
${ }^{5}$ Sugiyono. 2013.MetodePenelitianKuantitatif Kualitatif dan R\&D. Cetakan Ke-19. Bandung : Alfabeta hlm. 9.

${ }^{6}$ Jailan, M. Syahran. RagamPenelitian Qualitative (Ethnografi, Fenomenologi, GroundedTheory, dan Studi Kasus).http://download.portalgaruda.org/article .php? article $=252708 \&$ val $=6813 \&$ title $=$ Ragam $\%$ 20Penelitian\%20Qualitative\%20(Ethnografi, $\% 20 \mathrm{Fenomenologi} \%$ 20Grounded\%20Theory, dan\%20Studi\%20Kasus) Hlm. 42. 7/1/2015.

${ }^{7}$ Ibid hlm. 42-43
}

Ada beberapa ciri-ciri pokok fenomenologis yang dilakukan oleh peneliti fenomenologis menurut Moleong (2007: 8), yaitu: (a) mengacu kepada kenyataan, dalam hal ini kesadaran tentang sesuatu benda secara jelas; (b) memahami arti peristiwa dan kaitan-kaitannya terhadap orang-orang yang berada dalam situasi-situasi tertentu; (c) memulai dengan diam. Para fenomenologis berasumsi bahwa kesadaran bukanlah dibentuk karena kebetulan oleh sesuatu hal yang lain daripada dirinya sendiri ${ }^{8}$.

Para fenomenologis berusaha memahami arti peristiwa dan kaitankaitannya terhadap orang-orang yang berada dalam situasi-situasi tertentu. Inkuiri fenomenologis memulai dengan diam. Diam merupakan tindakan untuk menangkap pengertian sesuatu yang sedang diteliti. Dalam hal ini ditekankan pada aspek subjektif dari perilaku orang. Dimana para peneliti berusaha masuk ke dalam dunia konseptual para subjek yang ditelitinya sedemikian rupa sehingga mereka mengerti apa dan bagaimana suatu pengertian yang dikembangkan oleh mereka disekitar peristiwa dalam kehidupan sehari-hari. Para fenomenologis percaya bahwa pada 
makhluk hidup tersedia berbagai cara untuk menginterpretasikan pengalaman melalui interaksi dengan orang lain. ${ }^{9}$

Sebagaimana yang telah dipaparkan bahwa langkah pertama dalam melakukan penelitian fenomenologi adalah meneliti fenomena yang akan dikembangkan. Selanjutnya peneliti mengembangkan pertanyaan penelitian. Data akan dikumpulkan melalui wawancara langsung, observasi, rekaman, catatan lapangan. Data yang dikumpulkan diperoleh dari wawancara mendalam antara peneliti dengan informan (subjek) ${ }^{10}$.

Dari paparan diatas dapat ditarik kesimpulan bahwa penelitian yang menggunakan pendekatan fenomenologi adalah sebuah penelitian yang mengamati tentang fenomena yang terjadi dalam kehidupan manusia, dimana para peneliti berusaha masuk ke dalam dunia konseptual para subjek yang ditelitinya sedemikian rupa sehingga mereka mengerti apa dan bagaimana suatu pengertian yang dikembangkan oleh mereka disekitar peristiwa dalam kehidupan sehari-hari. ${ }^{11}$

Dengan demikian, peneliti dapat menjelaskan, menggambarkan,

\footnotetext{
${ }^{9}$ Ibid.

${ }^{10}$ Ibid hlm. 43-44

${ }^{11}$ Ibid hlm. 44
}

menerangkan masalah penelitian yang peneliti angkat, yaitu sengketa tanah adat Betang Sangkuwu di Desa Tumbang Marak, Kecamatan Katingan Tengah, Kabupaten Katingan.

Dalam penelitian ini, penentuan lokasinya berada di Desa Tumbang Marak, Kecamatan Katingan Tengah, Kabupaten Katingan. Adapun yang menjadi alasan pemilihan tempat ini karena di desa tersebut terdapat permasalahan berupa sengketa tanah adat Betang Sangkuwu, yaitu terjadi perebutan hak kepemilikan tanah adat Betang Sangkuwu antara masyarakat lokal Desa Tumbang Marak dan penampil atau warga pendatang yang menetap di desa tersebut, sehingga terjadi konflik antar kedua pihak kelompok tersebut.

Jenis dan sumber data yang dipergunakan dalam penelitian adalah:

a. Data Primer

Data primer adalah data yang diperoleh secara langsung dari responden dan narasumber tentang obyek yang diteliti. Data primer dalam penelitian didapat dengan metode wawancara. Narasumber yang diwawancarai yaitu aparatur Desa Tumbang Marak, pihak kelompok masyarakat lokal Desa Tumbang Marak, 
pihak kelompok penampil, warga Desa Tumbang Marak (warga netral), Mantir Desa Tumbang Marak, serta Tim Terpadu penyelesaian konflik yaitu Camat Katingan Tengah, Mantir dan Damang Kecamatan Katingan Tengah, serta Kepala Bidang Kasi Pemerintahan Umum, Pemerintah Daerah Kabupaten Katingan, yang merupakan sumber data untuk penelitian ini.

b. Data Sekunder

Data sekunder adalah data berupa bahan yang diperlukan dalam penelitian sosial, meliputi dokumentasi berupa gambar/foto terkait penelitian serta setiap bahan tertulis baik berupa monografi desa, profil desa, bukti tertulis terkait tanah adat, dan lain sebagainya, serta pengumpulan data dengan meneliti catatan-catatan penting yang sangat erat hubungannya dengan obyek penelitian.

Dalam suatu penelitian, termasuk penelitian sosial pengumpulan data merupakan salah satu tahapan dalam proses penelitian dan sifatnya mutlak untuk dilakukan karena dari data yang diperoleh kita mendapatkan gambaran yang jelas tentang obyek yang diteliti, sehingga akan membantu dalam menarik suatu kesimpulan dari obyek atau fenomena yang akan diteliti. Untuk membantu penulis mendapatkan gambaran yang jelas mengenai fenomena yang diteliti, maka dibutuhkan data yang valid. Teknik pengumpulan data tersebut meliputi :

\section{Observasi}

Observasi dalam penelitian yang digunakan merupakan observasi yang digolongkan kedalam observasi partisipasi pasif (passive participation) yaitu peneliti datang ketempat orang yang diamati, tetapi tidak ikut terlibat dalam kegiatan tersebut ${ }^{12}$. Serta tergolong dalam observasi yang terus terang dan tersamar yaitu peneliti dalam melakukan pengumpulan data menyatakan terus terang kepada sumber data, bahwa ia sedang melakukan penelitian. Jadi, mereka yang diteliti mengetahui sejak awal sampai akhir tentang aktivitas peneliti. Tetapi dalam suatu saat peneliti juga tidak terus terang atau tersamar dalam observasi. Hal ini untuk menghindari kalau suatu data yang dicari merupakan suatu data yang dirahasiakan. Kemungkinan kalau dilakukan dengan terus terang, maka peneliti tidak akan diizinkan melakukan observasi $^{13}$.

\footnotetext{
${ }^{12}$ Sugiyono. 2013.

MetodePenelitianKuantitatifKualitatif dan $R \& D$. Cetakan Ke-19. Bandung : Alfabeta. Hlm. 227.

${ }^{13}$ Ibid hlm. 227-228.
} 
Adapun manfaat observasi menurut Patton dan Nasution dalam Sugiyono (1988) yaitu : ${ }^{14}$

a. Peneliti akan lebih mampu memahami konteks data dalam keseluruhan situasi sosial, jadi akan diperoleh pandangan yang holistik atau menyeluruh.

b. Diperoleh pengalaman langsung, sehingga memungkinkan peneliti menggunakan pendekatan induktif, jadi tidak dipengaruhi oleh konsep atau pandangan sebelumnya.

Pendekatan induktif membuka kemungkian melakukan penemuan atau discovery.

c. Peneliti dapat melihat hal-hal yang kurang atau tidak diamati oleh orang lain, khususnya orang yang berada dalam lingkungan itu, karena telah dianggap "biasa" dan karena itu tidak akan terungkapkan dalam wawancara.

d. Peneliti akan menemukan hal-hal yang sedianya tidak akan terungkapkan oleh responden dalam wawancara karena bersifat sensitif atau ingin ditutupi karena dapat merugikan nama lembaga.

e. Peneliti dapat menemukan hal-hal yang di luar persepsi responden,

\footnotetext{
${ }^{14}$ Ibid., Hlm. 228.
}

sehingga peneliti memperoleh gambaran yang lebih komprehensif.

f. Peneliti tidak hanya mengumpulkan data yang kaya, tetapi juga memperoleh kesan-kesan pribadi, dan merasakan suasana situasi sosial yang diteliti.

Adapun pemilihan teknik pengumpulan data observasi partisipasi pasif selain yang dipaparkan tersebut, juga karena peneliti dalam melakukan penelitian dimana posisi peneliti tidak terlibat sama sekali dalam proses konflik, namun posisi peneliti hanya sekedar mengamati atau melihat keadaan/kenyataan secara langsung apa yang terjadi di Desa Tumbang Marak terkait penelitian yang peneliti lakukan. Hal ini bertujuan, agar peneliti menjadi orang yang netral dalam penelitian, guna memperoleh informasi yang seimbang dari beberapa pihak terkait masalah penelitian.

\section{Wawancara}

Esterberg dalam Sugiyono (2000) wawancara adalah pertemuan dua orang untuk bertukar informasi dan ide melalui tanya jawab, sehingga dapat dikonstruksikan makna dalam suatu topik tertentu. Susan Stainback dalam Sugiyono (1998), dengan wawancara maka peneliti akan mengetahui hal-hal 
yang lebih mendalam tentang partisipan dalam menginterpretasikan situasi dan fenomena yang terjadi, dimana hal ini tidak bias ditemukan pada observasi ${ }^{15}$.

Esterberg dalam Sugiyono (2002), mengemukakan wawancara semi struktur. Jenis wawancara ini yang digunakan dalam penelitian ini, dimana sudah termasuk dalam kategori in-dept interview, dalam pelaksanaannya lebih bebas. Tujuan dari wawancara jenis ini adalah untuk menemukan permasalahan secara lebih terbuka, dimana pihak yang diajak wawancara diminta pendapat, dan ide-idenya. Dalam melakukan wawancara, peneliti perlu mendengarkan secara teliti dan mencatat apa yang dikemukakan oleh informan ${ }^{16}$.

Tujuan dari teknik wawancara tak berstruktur yang peneliti pilih ini guna menganalisis permasalahan dari masalah yang peneliti angkat.

Dalam penelitian yang menjadi sebanyak dua puluh orang (20 orang) informan, yaitu :

a. Aparatur Desa Tumbang Marak (dua orang).

b.Mantir Desa Tumbang Marak (dua orang).

\footnotetext{
${ }^{15}$ Ibid., Hlm. 231-232.

${ }^{16}$ Ibid hlm. 233-234.
}

c. Warga Desa Tumbang Marak atau warga netral (empat orang).

d. Pihak kelompok masyarakat lokal Desa Tumbang Marak (empat orang).

f. Pihak Kelompok warga pendatang yang menetap di Desa Tumbang Marak atau disebut Penampil (empat orang).

g. Tim terpadu sengketa tanah adat Betang Sangkuwu di Desa Tumbang Marak (empat orang) meliputi :
Kepala
Bidang
Kasi
Pemerintahan
Umum,

Pemerintah Daerah Katingan

(satu orang).

> Camat Katingan Tengah (satu orang) Mantir Kecamatan Katingan Tengah (satu orang).

> Damang Kecamatan Katingan Tengah (satu orang).

Adapun kriteria informan penelitian, yaitu :

a. Berdasarkan lamanya tinggal / lama domisili di Desa Tumbang Marak (5 tahun-keatas).

b. Berdasarkan usia (25 tahun- keatas).

c. Berdasarkan peran fungsional di Desa Tumbang Marak / Aparatur Desa Tumbang Marak.

d. Berdasarkan pekerjaan. 
3. Dokumen

Dokumen merupakan catatan peristiwa yang sudah berlalu. Dokumen yang digunakan dalam penelitian ini berbentuk monografi desa, profil desa, hasil perjanjian kesepakatan pembuatan batas tanah adat. Dokumen yang berbentuk gambar misalnya foto ataupun gambar terkait keperluan penelitian. Studi dokumen merupakan pelengkap dari penggunaan metode observasi dan wawancara dalam penelitian kualitatif. ${ }^{17}$

Menurut Miles dan Huberman 1984, bahwa penelitian ini menggunakan teknik analisa data interaktif. Model interaktif ini terdiri dari tiga hal utama reduksi data, pengkajian data, penarikan kesimpulan atau verifikasi. Analisis ini merupakan sebuah proses yang berulang dan berlanjut secara terus-menerus. (Miles dan Huberman, 1984 ).

1. Reduksi data adalah proses pemilihan atau seleksi, pemusatan perhatian pada penyederhanaan dan pengabstrakan data yang berlangsung terus hingga laporan akhir penelitian disusun. Proses reduksi data untuk lebih menajamkan, menggolongkan, mengarahkan serta mengorganisasikan data sehingga memudahkan untuk dilakukan

\footnotetext{
${ }^{17}$ Ibi., Hlm. 240
}

penarikan kesimpulan yang akan di lanjutkan dengan proses verifikasi.

2. Pengkajian data adalah sebagai sekumpulan informasi tersusun yang memberi kemungkinan adanya penarikan kesimpulan dan pengambilan tindakan selanjutnya.

3. Penarikan kesimpulan dan verifikasi dengan menggunakan komponen utama yaitu reduksi data, pengkajian data, penarikan kesimpulan dan verifikasi, akan memudahkan peneliti untuk menganalisa data yang diperoleh dalam penelitian mengenai sengketa tanah adat Betang Sangkuwu di Desa Tumbang Marak, Kecamatan Katingan Tengah, Kabupaten Katingan (analisis konflik terhadap perebutan hak kepemilikan tanah adat Betang Sangkuwu).

\section{HASIL DAN PEMBAHASAN}

\section{Peran Otoritas}

Seperti yang dikemukakan Dahrendrof yang menganalisis konflik dengan mengidentifikasi berbagai peran otoritas dan kekuasaan dalam masyarakat. Ia mendefinisikan kekuasaan : "Kemungkinan bahwa satu aktor dalam suatu hubungan sosial akan berada dalam posisi melakukan perlawanan tanpa melihat kemungkinan 
perlawanan itu menyerah" (Dahrendrof. 1959:166). Hal ini terlihat pada otoritas yang dimiliki Bapak. Guyur sebagai Kepala Desa Tumbang Marak yang memegang kekuasaan di desa tersebut dengan menggerakkan masyarakat asli Desa Tumbang Marak untuk melakukan perlawanan terhadap pihak Penampil.

Dahrendorf mengatakan pertentangan yang terjadi karena golongan yang berkuasa berusaha mempertahankan status quo. Hal tersebut terlihat dimana Bapak. Guyur selaku Kepala Desa Tumbang Marak bersama aparatur desa Tumbang Marak dan melibatkan Mantir Desa Tumbang Marak mempertahankan kepemilikan tanah adat Betang Sangkuwu adalah milik masyarakat asli Desa Tumbang Marak selain karena cerita dari pembakas Lewu tentang kepemilikan Betang Sangkuwu adalah milik nenek moyang masyarakat asli Desa Tumbang Marak, juga karena lokasi berdirinya Betang Sangkuwu berada di wilayah Desa Tumbang Marak.

Dahrendorf melihat yang terlibat konflik adalah kelompok semu (quasi group), yaitu para pemegang kekuasaan atau jabatan dengan kepentingan yang sama karena munculnya kelompok kepentingan. Hal ini dilihat dari keterlibatan kepala desa sebagai penggerak pihak kelompok masyarakat asli Desa Tumbang Marak dan keterlibatan sekretaris desa dan mantir adat desa sebagai anggota pihak kelompok masyarakat asli Desa Tumbang Marak dengan kepentingan yang sama.

Dahrendorf, adapun kelompok kedua adalah kelompok kepentingan yang terdiri dari kelompok semu yang lebih luas. Kelompok kepentingan ialah yang menjadi sumber nyata timbulnya konflik dalam masyarakat. Hal ini dilihat bahwa konflik bermula dari pengklaiman dan tuntutan pihak kelompok Penampil tentang kepemilikan Betang Sangkuwu.

\section{Konflik Laten}

Kepentingan laten adalah tingkah laku potensil ("undercurrents behavior") yang telah ditentukan bagi seseorang karena dia menduduki peranan tertentu tetapi masih belum disadari. Artinya, tingkah laku potensil merupakan tingkah laku yang dapat memunculkan konflik, namun tidak disadari. Hal ini temukan bahwa konflik perebutan hak kepemilikan Betang Sangkuwu telah mengarah kepada sikap saling curiga dan saling gunjing antar pihak berkonflik, 
dan saling ancam antara kedua pihak berkonflik.

\section{Konflik Manifest}

Dalam konflik yang terjadi antar pihak kelompok Penampil dengan pihak kelompok masyarakat asli Desa Tumbang Marak, terdapat konflik manifest yaitu kepentingan-kepentingan yang terwujud kepermukaan dalam bentuk tujuan-tujuan yang disadari, hal ini terwujud dalam bentuk saling tuntut mengajukan tuntutan antar kedua pihak yang berkonflik tentang siapa yang berhak memiliki tanah adat tersebut, seperti :

Adanya pihak Penampil yang membuat laporan hak kepemilikan tanah adat Betang Sangkuwu yang disampaikan kepada Damang Kecamatan sehingga dilaksanakan upacar adat Dayak Hinting, serta adanya upayaupaya pengumpulan bukti dari pihak kelompok masyarakat Desa Tumbang Marak baik meminta dukungan dengan pembakas lewu terkait yang mengetahui asal usul Betang Sangkuwu, dan juga adanya upaya pembuatan silsilah keturunan baik dari pihak kelompok Penampil, ataupun pihak kelompok masyarakat asli Desa Tumbang Marak. Serta upaya pengaduan ke kabupaten sehingga ditempuhnya mediasi sekitar bulan Oktober 2014 yang difasilitasi oleh Pemerintah Daerah Katingan melalui Tim Terpadu yang dibentuk berdasarkan SK dari Sekretaris Daerah.

\section{Faktor Penghambat Upaya Penyelesaian Sengketa}

\section{a. Sikap gengsi sosial budaya : nilai harga diri}

Jadi terdapat sikap gengsi sosial budaya berupa nilai harga diri yang kuat oleh pihak Penampil yaitu, antara lain :

Sikap dimana tidak adanya keinginan dari pihak Penampil untuk mundur dari konflik karena penggerak sudah memobilisasi dan menjanjikan kepada anggotanya bahwa Betang Sangkuwu adalah milik Desa Rantau Asem, serta janji mengenai per kepala keluarga akan mendapatkan bagian masing-masing Rp 30.000.000,/KK (tiga puluh juta Rupiah per kepala keluarga), sedangkan hasil Mediasi tidak memenuhi hal tersebut. Jadi, hal itu yang membuat pihak kelompok Penampil yang saat ini di gandengi oknum $\mathrm{KCW}$ enggan untuk mundur dari konflik dan 
akan mengangkat masalah ke ranah hukum positif (pengadilan). Dengan kata lain terdapat nilai harga diri dari penggerak kelompok tersebut guna mempertahankan tujuannya.

Sikap dimana adanya keinginan besar dari pihak Penampil dalam mempertahankan tanah adat Betang Sangkuwu dijadikan sebagai situs budaya guna melestarikan peninggalan nenek moyang mereka atas nama Temanggung Doho nenek moyang Desa Rantau Asem, sedangkan hasil mediasi tidak mengeluarkan hasil tentang siapa yang memiliki hak kepemilikan tanah adat Betang Sangkuwu. Hal ini terkait dengan pihak Penampil yang telah mengakui dan memperjuangkan tujuannya bahwa mereka adalah keturunan Temanggung Doho.

\section{b. Kekerasan Langsung}

Adapun digunakannya konsep kekerasan Johan Galtung dalam penelitian, guna menjadi teori pendukung yang menjelaskan tentang konflik bersifat Laten serta adanya hubungan antar kedua teori tersebut sama-sama merupakan teori struktural. Dalam teori Dahrendorf yang peneliti identifikasi yaitu berupa saling ancam merupakan salah satu bentuk konflik Laten, sedangkan hal tersebut dalam konsep kekerasan Johan Galtung termasuk dalam kekerasan langsung. Bahwa kekerasan langsung itu tidak hanya dengan kekerasan menimbulkan korban fisik, tetapi juga ada kekerasan langsung dengan bentuk lain. Johan Galtung "Ancaman atau teror dari satu kelompok yang menyebabkan ketakutan dan trauma psikis juga merupakan bentuk kekerasan langsung" ${ }^{18}$. Hal tersebut peneliti identifikasi sebagai sebuah ancaman atau teror, dimana dengan adanya saling ancam membuat masyarakat Desa Tumbang Marak menjadi ketakutan.

\section{c. Kekerasan Kultural}

Galtung menekankan makna kekerasan budaya yang ia maksud bukanlah hendak menyebut kebudayaan sebagai keseluruhan sistemnya, namun aspek-aspek dari kebudayaan itu. Galtung memberi definisi kekerasan budaya "kekerasan budaya adalah aspekaspek dari kebudayaan, ruang simbolis

\footnotetext{
18 Santoso, Thomas. 2002. Cetakan pertama. Teori-TeoriKekerasan. Surabaya : Ghalia Indonesia Hlm. 122.
} 
dari keberadaan masyarakat manusia dicontohkan oleh agama dan ideologi, bahasa dan seni, ilmu pengetahuan empiris dan formal (logis, materis)- yang bisa digunakan untuk menjustifikasi atau melegitimasi kekerasan struktural dan langsung.' (Galtung, 1990: 291) ${ }^{19}$. Galtung menjelaskan bahwa atribut budaya dapat digunakan sebagai bentuk perlawanan, terkait hal tersebut dimana terdapat perlawanan dari pihak Penampil dengan bentuk melakukan Hinting Pali (mediasi secara adat Dayak) yang ditempuh sebagai jalan lain dari pihak Penampil, karena selama ini ketika pihak Penampil berurusan melalui prosedur perusahaan selalu dipersulit.

\section{Penyebab Konflik}

\section{a. Akar konflik}

Pertama, keberadaan perusahaan.

Dari temuan data bahwa sebelum berdirinya perusahaan di sekitar tanah adat Betang Sangkuwu tidak pernah terjadi konflik perebutan hak kepemilikan atas tanah adat Betang Sangkuwu. Kedua, perbedaan versi cerita tentang kepemilikan tanah adat, pihak masyarakat asli memiliki cerita bahwa kepemilikan tanah adat tersebut adalah milik Oko Apang Beren yaitu

\footnotetext{
19 Ibid hlm. 123.
}

nenek moyang masyarakat asli Desa tumbang Marak, sedangkan pihak kelompok Penampil memiliki cerita bahwa tanah adat tersebut milik nenek moyang mereka yaitu Temanggung Doho orang Desa Rantau Asem. Ketiga, perbedaan tuntutan dimana pihak masyarakat asli desa menuntut agar dijadikan situs budaya Betang Sangkuwu milik masyaakat Desa Tumbang Marak, sedangkan pihak Penampil menuntut tanah adat Betang Sangkuwu di jadikan situs budaya milik nenek moyang Desa Rantau Asem, dan meminta agar pihak perusahaan membayar denda karena terpakai tanah adat Betang Sangkuwu.

\section{b. Pemicu konflik}

Pemicu konflik yang terjadi merujuk pada makna tanah menurut Fiona Atkins, arti penting tanah itu pada hakikatnya muncul karena tanah mempunyai apa yang dinamakan Fiona Atkins (1990) sebagai Rent. ${ }^{20}$

Mengingat tanah tersebut merupakan tanah adat tempat untuk memuja Sang Pencipta (nilai sakralbudaya) atau termasuk pada Rent Ricardian sehingga adanya tuntutan agar Betang Sangkuwu dijadikan situs

\footnotetext{
${ }^{20}$ Suharso Pujo. 2002. Tanah, Petani, Politik Pedesaan.Cetakan Pertama. Solo : Pondok Edukasi
} 
budaya. Tanah adat tersebut secara jelas mengandung nilai ekonomi yaitu dengan adanya tuntutan pihak Penampil kepada perusahaan untuk ganti rugi tanah terpakai seluas $10.000 \mathrm{Ha}$ (sepuluh ribu Hektar) sebesar Rp. 32 Miliyar (tiga puluh dua Miliyar rupiah). Sengketa tanah adat yang terjadi tidak lepas dari apa yang disebut dengan Rent Sosial, dimana adanya upaya mempertahankan kepemilikan tanah adat Betang Sangkuwu oleh masyarakat asli Desa Tumbang Marak, guna memegang teguh peninggalan nenek moyang mereka. Dalam hal tersebut terdapat sosial previlages atau harga diri sebagai masyarakat asli Desa Tumbang Marak.

\section{KESIMPULAN}

Sengketa tanah adat Betang Sangkuwu di desa Tumbang Marak sudah terjadi pada tahun 2005, dan mulai menguak pada tahun 2013, dan pada tahun 2014 sengketa terangkat ke Kabupaten. Perebutan hak kepemilikan tanah adat yang berada di tengah perkebunan perusahaan pengolahan kelapa sawit PT. Karya Dewi Putera, dengan luas tanah adat $\pm 25 \mathrm{Ha}$ (dua puluh lima Hektar), berada di Blok L34 dengan titik koordinat $\mathrm{X} 112.890235$ dan Y 1.445735, dimana kondisi Betang
Sangkuwu di Desa Tumbang Marak hanya sisa-sisa bangunan saja. Penyebab konflik, dan konflik yang terjadi yang dikaitkan dengan Rent Ricardian, dan Rent Social (harga diri), dan nilai ekonomi saling berhubungan. Dimana, penyebab konflik dapat membentuk konflik Laten dan konflik Manifest karena adanya aktor (peran otoritas) dan atau pelaku konflik yang menggerakkan, melakukan perlawanan untuk mempertahankan dan memperjuangkan tujuan ataupun kepentingan baik nilai harga diri atau Rent Social, Rent Ricardian, dan adanya nilai ekonomi tanah adat Betang Sangkuwu. Konflik yang terjadi telah menempuh upaya penyelesaian yaitu secara mediasi yang diadakan di Kabupaten Kasongan dan Hinting Pali (denda adat) secara adat Dayak yang diadakan di lokasi sengketa, yang difasilitasi oleh Tim Terpadu dengan melibatkan pihak perusahaan, warga Desa Tumbang Marak, dan kedua pihak yang berkonflik. Kondisi saat ini, konflik antar kedua kelompok sudah meredam, sedangkan kepemilikan tanah adat Betang Sangkuwu belum diketahui siapa yang berhak memilikinya.

Berdasarkan analisa konflik terhadap perebutan hak kepemilikan tanah adat Betang Sangkuwu, 
pandangan penulis terhadap penyelesaian akhir dari sengketa tanah adat Betang Sangkuwu bahwa, ditemukan penyelesaian yang sulit terhadap sengketa yang terjadi. Sengketa tidak akan dapat terselesaikan sejauh kedua pihak kelompok yang memperebutkan hak kepemilikan tanah adat Betang Sangkuwu tidak melakukan kesepakatan mengenai siapa nama dari kepemilikan Betang Sangkuwu. Untuk melakukan hal tersebutpun, perlu dilakukan penelusuran terlebih dahulu mengenai siapa itu Oko Apang Beren, dan siapa itu Temanggung Doho. Hendaknya perlu penelitian mendalam dengan melibatkan para ahli yang memang dapat membuktikan dengan ilmiah tentang asal usul dan siapa keturunan dari pemilik Betang Sangkuwu. Adapun, yang menjadikan masalah ini sulit diselesaikan adalah tuntutan yang berbeda terkait dengan adanya nilai ekonomi tanah adat Betang Sangkuwu, melihat kemungkinan jika tuntutan ini terus dan tetap diperjuangkan maka keberatan dari pihak perusahaan dalam memenuhi tuntutan tersebut.

Adapun kritikan bagi pihak LSM atau organisasi yaitu $\mathrm{KCW}$, serta Aparatur Desa Tumbang Marak dan
Mantir Desa Tumbang Marak hendaknya tidak memihak salah satu pihak tetapi benar-benar menjadi penengah dalam masalah ini, dan harusnya memperhitungkan kepentingan bagi masyarakat Desa Tumbang Marak secara keseluruhan. Harusnya penyelesaian masalah ini seimbang, sehingga tidak ada pihak yang merasa dirugikan agar benar-benar kedua pihak dapat menerima keputusan tanpa keberatan, sehingga tanah adat Betang Sangkuwu dapat dimanfaatkan secara bersama dan semestinya, sesuai kegunaannya.

\section{DAFTAR PUSTAKA}

Berita Acara Kesepakatan Pembuatan Batas Tanah Adat tgl 14 Maret 2005 \& 27 Maret 2005 di Tumbang Marak.

Dahrendorf, Ralf. 1986. Konflik dan Konflik Dalam Masyarakat industri: Sebuah Analisis Kritik / Ralf Dahrendorf ; Penerjemah, Ali Mandan. Edisi 1, Cetakan. Jakarta : Rajawali.

Jailan, M. Syahran. Ragam Penelitian Qualitative (Ethnografi, Fenomenologi, Grounded Theory, dan Studi Kasus).http://download.portalgar uda.org/article.php? article $=25270$ $8 \&$ val $=6813 \&$ title $=$ Ragam $\% 20 \mathrm{P}$ enelitian\%20Qualitative\%20(Eth nografi,\%20Fenomenologi,\%20G 
rounded\%20Theory,dan\%20Stud i\%20Kasus) 7 /1/2015.

Limbong, Bernhard. 2012. Konflik Pertanahan. Jakarta Selatan : Margaretha Pustaka.

Narwoko, Dwi J. \&Suyanto, Bagong.2004. Edisi Keempat. Sosiologi : Teks Pengantar Dan Terapan. Jakarta : Kencana.

Santoso, Thomas. 2002. Cetakan pertama. Teori-Teori Kekerasan. Surabaya : Ghalia Indonesia.

Suharso, Pujo. 2002. Tanah, Petani, Politik Pedesaan.Cetakan Pertama. Solo : Pondok Edukasi.

Susan, Novri. 2010. EdisiPertama, Cetakan Ke-2.Pengantar Sosiologi Konflik dan Isu-Isu Kontemporer. Jakarta : Kencana.

Sugiyono. 2013. Metode Penelitian Kuantitatif Kualitatif dan $R \& D$. Cetakan Ke-19. Bandung : Alfabeta.

Usop, Sidik. R. Kebijakan Pemerintah Provinsi Kalimantan Tengah Terhadap MasyarakatAdat.http://Www.Gcf taskforce.Org/Documents/May_ Aceh/Side_Event_Presentations/ Sidik\%20usop,\%20kebijakan\%2 0pemerintah\%20provinsi\%20kali mantan\%20tengah\%20terhadap\% 20masyarakat\%20adat.Pdf16/12/ 2014.
Peraturan Gubernur Kalimantan Tengah nomor 13 tahun 2009 Tentang Tanah Adat Dan Hak-Hak Di Atas Tanah Di Provinsi Kalimantan Tengah.

Wirawan, I.B. 2012. Teori-Teori Sosial Dalam Tiga Paradigma (Fakta Sosial, Definisi Sosial, dan Perilaku Sosial). Cetakan ke-1. Jakarta : Kencana Prenada Media Group.

Widen, Kumpiyadi. http://kumpiadywiden.com/2013/ 01/23/potensi-konflik-dalam-eraotonomi-daerah-di-kalimantantengah/ . 16/12/2014 